Original Research Paper

\title{
Normative Data Obtained in Testing the Sense of Hearing in Kangal Shepherd Dogs
}

\author{
${ }^{1}$ Mustafa Koçkaya, ${ }^{2}$ Yusuf Özşensoy and ${ }^{3}$ Hakan Murat \\ ${ }^{I}$ Department of Veterinary Physiology, \\ Sivas Cumhuriyet University, Faculty of Veterinary Medicine, Sivas, Turkey \\ ${ }^{2}$ Department of Veterinary Biometrics and Genetics, \\ Sivas Cumhuriyet University, Faculty of Veterinary Medicine, Sivas, Turkey \\ ${ }^{3}$ Department of Livestock Economics and Management, \\ Sivas Cumhuriyet University, Faculty of Veterinary Medicine, Sivas, Turkey
}

\section{Article history}

Received: 22-06-2019

Revised: 05-08-2019

Accepted: 21-08-2019

Corresponding Author:

Yusuf Özşensoy

Department of Veterinary

Biometrics and Genetics, Sivas

Cumhuriyet University, Faculty of Veterinary Medicine, Sivas, Turkey

Email: yusufozsensoy@yahoo.com

\begin{abstract}
Sense of hearing is of crucial importance for dogs to perform their duties. There is no study to determine the reference latency intervals of dogs' sense of hearing. The aim of this study is to identify normative data that can be used as the reference interval for the wave latencies I, III and V at $80 \mathrm{~dB}$ with respect to the sense of hearing of Kangal shepherd dogs. The Brainstem Auditory Evoked Response test was applied to 106 Kangal shepherd dogs in Sivas province. The animals have been grouped by age, sex and general. Normative data were identified for the reference latency intervals for each wave of the right and left ears of the groups and statistical differences between the wave latency intervals were also examined. One-Way ANOVA and post-hoc Duncan test were used in the age group comparison and independent samples t-test was used in the comparison of the other groups. All statistical analyses were performed using the SPSS v.22 software. When the groups are compared, only statistically significant difference was found in the age group at the wave latency V at $80 \mathrm{~dB}$ HL. No statistically significance was found in all other groups. The average values of the wave latencies I, III and $\mathrm{V}$ were found to be $1.37-2.36-3.65 \mathrm{~ms}, 1.37-2.35-3.63 \mathrm{~ms}, 1.38-2.36-$ $3.68 \mathrm{~ms}, 1.35-2.37-3.79 \mathrm{~ms}, 1.30-2.26-3.57 \mathrm{~ms}$ and 1.41-2.39-3.59, general, female, male, 20 day -9 month, 10-30 month and 31 months and older, respectively. Since normative data on the sense of hearing of Kangal shepherd dogs have been identified for the first time with this study, it is expected to make a significant contribution to the literature. This normative data can be used as reference interval in clinical examinations and future studies on the sense of hearing of Kangal shepherd dogs.
\end{abstract}

Keywords: BAER, Kangal Shepherd Dog, Normative Data, Turkey, Wave Latency V

\section{Introduction}

The importance of Kangal shepherd dogs as herd protection and guard dogs is increasing every day in the world. In some countries, Kangal shepherd dogs are used to protect endangered animals (Kartay, 2003; Koçkaya and Şireli, 2015). The reason why Kangal shepherd dogs' importance and popularity is on rise in the world is the fact that they perfectly fulfil all the duties they are assigned with. Kangal shepherd dogs' fulfilling the given tasks perfectly, is, of course, due to the fact that they have superior sense organs. One of these sense organs is the sense of hearing. Kangal shepherd dogs that are used in pasture-crop husbandry are desired to be healthy. Having a robust sense of hearing, which is among the health criteria and is actively used especially in heard management, is extremely important for Kangal shepherd dogs in terms of both feeling itself safe and getting the commands and receiving the danger signals it is supposed to perceive. Otherwise, the herd may be vulnerable to wild animal attacks and theft at any time and may suffer heavy losses. Similarly, if the dogs used as guard dogs do not have a good sense of hearing, the places they guard will be vulnerable to dangerous situations (Koçkaya et al., 2019). 
The process from the collection of sound waves in the atmosphere by the ear to the perception of character and meaning in the respective centers of the brain is called hearing (Akyıldız, 1998). The outer ear directs the sound waves it receives to the middle ear. The middle ear then transmits the sound vibrations to the inner ear. This transmission occurs in two ways; sound waves either pass through the oval window to the perilymph with the vibration of the eardrum and the ossicular system, or sound waves pass through the round and oval window to the perilymph with the vibration of the air in the middle ear and eardrum (Paparella et al., 1991). A movement occurs in the perilymph and vibrations emerge in the basilar membrane as the sound waves pass to the perilymph.

The basilar membrane movements are related to those of the streocillia. The inner and outer streocillia that are on the corti organ take part in the transformation of sound energy into nerve energy. The action potential reaching the hearing center through the nerve is given a meaning and hearing occurs (Cummings et al., 1998; Ballenger and Snow, 2000; Yaman, 2004). Hearing test techniques are well developed and one of these techniques is the Auditory Brainstem Response (ABR) test technique. The basic characteristic of this test technique is the evaluation of electrophysiological functions from cochlea to subcortical structures. This test is used to have information about the latency and amplitude of the sound waves by sending click stimuli. In ABR tests, generally the waves between I and V are observed and among these waves, the waves I, III and V and the distance in between them is analysed (Parlak,
2014). In general, the latency differences between the waves I-III, III-V, I-V are used to clinically investigate the hearing ability of live beings.

Dogs' sense of hearing is the same as humans, yet much more powerful. This difference can be explained with the improvement of organs in line with the needs. Dogs are capable of hearing high frequency sounds coming from a longer distance in comparison to humans (Stepien et al., 1990; Sanders, 2000; Dalziel et al., 2003; Case, 2005). Loss of this ability can be caused by various reasons (Hayes et al., 2010; Lv et al., 2010; Strain, 2011; Comito et al., 2012) and this situation adversely affects the well-being and life of animals (Keele et al., 1985; Strain, 2012). No literature has been found on the sense of hearing data in Kangal shepherd dogs. Identification of hearing data intervals in Kangal shepherd dogs will be useful in determining the hearing function ability of these animals in clinical studies.

The aim of this study is to create normative data with reference latency intervals of Kangal shepherd dogs by identifying the wave latencies I, III and V and latency intervals at $80 \mathrm{~dB}$ HL (Decibel Hearing Level) of Kangal shepherd dogs with normal hearing capability through click stimuli.

\section{Materials and Methods}

Ethics committee approval was granted by the Cumhuriyet University Local Ethics Committee for Animal Experimentation (decision dated 02-23-2016 and numbered 65202830-050.04.04-25).

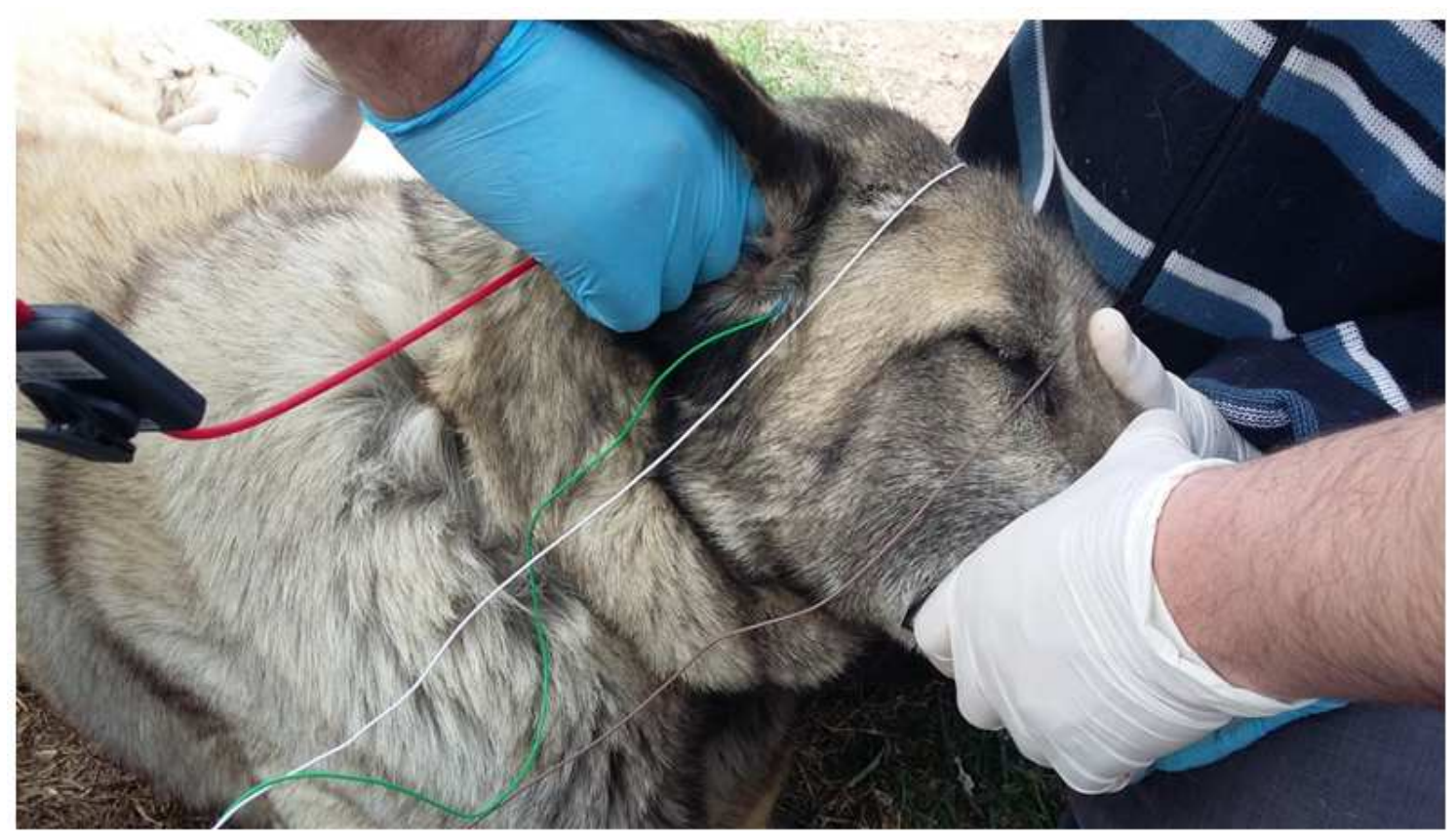

Fig. 1: Placement of the electrodes and speakers 


\section{Animals and BAER Test}

A total of 106 Kangal shepherd dogs, 55 female and 51 male, aged between 20 days and 10 years and breed by the local people and breeding farms in Sivas province center and districts construct the animal material of the study. Each dog was subjected to a hearing test with Otometrics ICS Chartr EP 200 clinical ABR device. Once the dogs were accustomed to the person to conduct the hearing test and the hearing test method, the hearing test data were recorded. By getting the dog accustomed to the hearing test, the artefacts that might occur during the test and the stresses that might emerge in the dogs were prevented. The first skin recording electrode of the system was placed at the top of the animal's head, the second in front of the left ear and the third in front of the right ear (Fig. 1). In the breeding environment of the dogs, speakers were placed on both right and left ears respectively, click stimuli were sent at $80 \mathrm{~dB} \mathrm{HL}$ and I, III and V wave latencies were identified.

\section{Statistical Analyses}

The animals were divided into different groups as general, sex and age. In the general category, all animals were treated as a single group and left and right wave latencies were compared. When it comes to the groups categorized by sex and age, the mean of the wave latencies I, III and V of their right and left ears were calculated and made a single data and statistical analyses were run accordingly. The difference between wave latencies obtained from the sex group and general group was identified through independent samples $t$ test. OneWay ANOVA and post-hoc Duncan test were run to see whether there is a significant difference between the wave latencies of the data categorized into three groups as 20 days- 9 months, 10 months- 30 months and 31 months and older in terms of age. All statistical analyses were run using SPSS v.22 for Windows package software (SPSS Inc, 2013). The data are shown in the form of mean \pm standard error of mean.

\section{Results}

The wave latencies I, III and V of sense of hearing at $80 \mathrm{~dB}$ HL were obtained with the ICS Chapter program (Fig. 2).

Maximum, minimum and mean values of the wave latencies I, III and V of right and left ears at $80 \mathrm{~dB} \mathrm{HL}$, which was determined as the reference interval, of a total of 106 animals are shown in Table 1.

Statistical comparisons of the wave latencies I, III and $\mathrm{V}$ of right and left ears of a total of 106 animals in general at $80 \mathrm{~dB} \mathrm{HL}$, are shown in Table 2. In general, no difference was found between wave latencies in terms of hearing threshold $(\mathrm{P}>0.05)$.

Statistical comparisons of the wave latencies I, III and $\mathrm{V}$ of a total of 106 animals by sex at $80 \mathrm{~dB}$ HL are given in Table 3. Whether there is difference between the wave latencies of animals by sex has been examined and no difference was found in terms of hearing threshold $(\mathrm{P}>0.05)$.

Statistical comparisons of the wave latencies I, III and $\mathrm{V}$ of a total of 106 animals by age at $80 \mathrm{~dB} \mathrm{HL}$ are given in Table 4 . Whether there is difference between the wave latencies of animals by age has been examined and no difference was found in terms $80 \mathrm{~dB} \mathrm{HL}-\mathrm{I}$ and $80 \mathrm{~dB}$ HL - III hearing threshold $(\mathrm{P}>0.05)$. The only difference between the age groups was found in terms of the $80 \mathrm{~dB}$ HL $-\mathrm{V}$ hearing threshold $(\mathrm{P}<0.05)$.

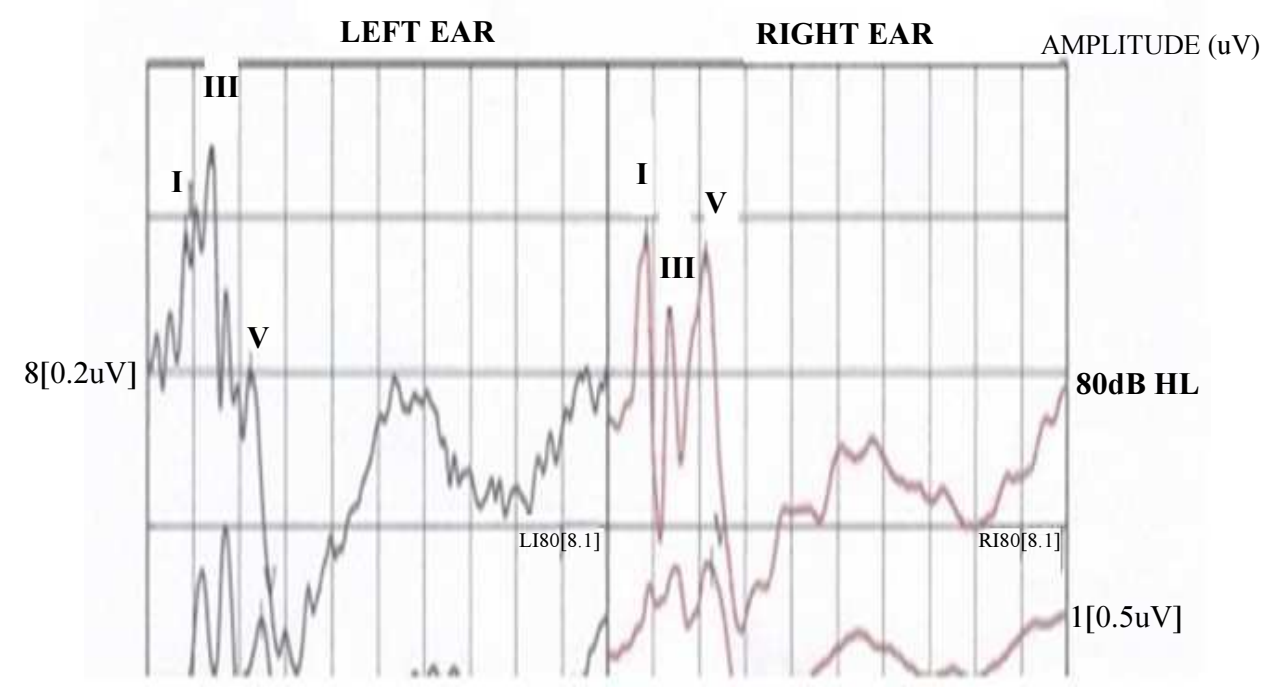

Fig. 2: Waves obtained regarding hearing 
Mustafa Koçkaya et al. / American Journal of Animal and Veterinary Sciences 2019, 14 (3): 170.175 DOI: 10.3844/ajavsp.2019.170.175

Table 1: Reference values (Min-Max-Mean) of right and left ear and general wave latencies according to groups in $80 \mathrm{~dB}$ HL (ms)

\begin{tabular}{|c|c|c|c|c|c|c|}
\hline \multirow[b]{3}{*}{ Wave latencies } & \multicolumn{6}{|l|}{ Groups } \\
\hline & \multirow{2}{*}{$\begin{array}{l}\text { General } \\
(\mathrm{n}=106)\end{array}$} & \multicolumn{2}{|l|}{ Gender } & \multicolumn{3}{|l|}{ Age } \\
\hline & & Female $(\mathrm{n}=55)$ & Male $(\mathrm{n}=51)$ & 20 day-9 month $(\mathrm{n}=35)$ & $10-30$ month $(\mathrm{n}=20)$ & 31 months and older $(\mathrm{n}=51)$ \\
\hline \multicolumn{7}{|l|}{ RIGHT EAR } \\
\hline I & $0.78-2.43-1.35$ & $1.02-2.25-1.35$ & $0.78-2.43-1.36$ & $0.78-2.25-1.34$ & $1.05-1.63-1.31$ & $1.02-2.43-1.38$ \\
\hline III & $1.75-3.15-2.35$ & $1.95-2.95-2.33$ & $1.75-3.15-2.37$ & $1.75-3.10-2.37$ & $1.95-2.98-2.27$ & $2.00-3.15-2.36$ \\
\hline $\mathrm{V}$ & $2.68-4.68-3.61$ & $2.68-4.68-3.56$ & $3.00-4.53-3.67$ & $2.80-4.68-3.75$ & $2.68-4.10-3.56$ & $2.80-4.18-3.54$ \\
\hline \multicolumn{7}{|l|}{ LEFT EAR } \\
\hline I & $0.93-2.48-1.39$ & $1.08-2.48-1.39$ & $0.93-2.48-1.39$ & $1.08-2.33-1.37$ & $0.93-2.28-1.30$ & $1.10-2.48-1.44$ \\
\hline III & $1.78-3.50-2.37$ & $1.78-3.45-2.37$ & $1.78-3.50-2.36$ & $1.78-3.25-2.36$ & $1.88-3.50-2.26$ & $1.80-3.45-2.41$ \\
\hline $\mathrm{V}$ & $2.70-5.35-3.70$ & $2.70-5.35-3.70$ & $2.80-4.60-3.70$ & $3.08-5.35-3.84$ & $2.70-4.30-3.59$ & $2.80-4.73-3.65$ \\
\hline \multicolumn{7}{|c|}{ GENERAL WAVE LATENCY VALUES * } \\
\hline I & $0.94-2.38-1.37$ & $1.08-2.24-1.37$ & $0.94-2.38-1.38$ & $0.94-2.24-1.35$ & $0.99-1.81-1.30$ & $1.15-2.38-1.41$ \\
\hline III & $1.86-3.14-2.36$ & $1.96-3.02-2.35$ & $1.86-3.14-2.36$ & $1.86-2.94-2.37$ & $1.96-2.94-2.26$ & $2.01-3.14-2.39$ \\
\hline V & $2.69-5.02-3.65$ & $2.69-5.02-3.63$ & $2.92-4.29-3.68$ & $3.17-5.02-3.79$ & $2.69-4.12-3.57$ & $2.80-4.41-3.59$ \\
\hline
\end{tabular}
ms: millisecond, $\mathrm{n}$ : sample number, ${ }^{*}$ General wave latency values obtained by taking the average of right and left ears

Table 2: General comparisons of right and left ear wave latency values in $80 \mathrm{~dB}$ HL (ms)

\begin{tabular}{|c|c|c|}
\hline \multicolumn{3}{|l|}{ Right $(\mathrm{n}=106)$} \\
\hline I & III & $\mathrm{V}$ \\
\hline$\times \pm \mathrm{S} \times$ & $\times \pm \mathrm{S} \times$ & $\times \pm \mathrm{S} \times$ \\
\hline $1.35 \pm 0.023$ & $2.35 \pm 0.026$ & $3.61 \pm 0.039$ \\
\hline \multicolumn{3}{|l|}{ Left $(n=106)$} \\
\hline I & III & V \\
\hline$\times \pm \mathrm{S} \times$ & $\times \pm \mathrm{S} \times$ & $\times \pm \mathrm{S} \times$ \\
\hline $1.39 \pm 0.030$ & $2.37 \pm 0.034$ & $3.70 \pm 0.048$ \\
\hline \multicolumn{3}{|l|}{ P value } \\
\hline $\mathrm{P}>0.05$ & $\mathrm{P}>0.05$ & $\mathrm{P}>0.05$ \\
\hline
\end{tabular}

ms: millisecond, $\mathrm{n}$ : sample number, $\times \pm \mathrm{S} \times$ : mean \pm standard error of mean

Table 3: Comparisons of wave latency values according to genders' general values in $80 \mathrm{~dB}$ HL (ms)

\begin{tabular}{|c|c|c|}
\hline Female $(n=55)$ & & \\
\hline I & III & $\mathrm{V}$ \\
\hline$\times \pm \mathrm{S} \times$ & $\times \pm \mathrm{S} \times$ & $\times \pm \mathrm{S} \times$ \\
\hline $1.37 \pm 0.030$ & $2.35 \pm 0.032$ & $3.63 \pm 0.060$ \\
\hline Male $(n=51)$ & & \\
\hline I & III & V \\
\hline$\times \pm \mathrm{S} \times$ & $x \pm \mathrm{S} \times$ & $\times \pm \mathrm{S} \times$ \\
\hline $1.38 \pm 0.037$ & $2.36 \pm 0.039$ & $3.68 \pm 0.047$ \\
\hline$P$ value & & \\
\hline $\mathrm{P}>0.05$ & $\mathrm{P}>0.05$ & $\mathrm{P}>0.05$ \\
\hline
\end{tabular}

ms: millisecond, $\mathrm{n}$ : sample number, $\times \pm \mathrm{S} \times$ : mean \pm standard error of mean

Table 4: Comparisons of wave latency values according to ages' general values in $80 \mathrm{~dB}$ HL (ms)

\begin{tabular}{lll}
\hline 20 days-9 months $(\mathrm{n}=35)$ & $\mathrm{III}$ & $\mathrm{V}$ \\
$\mathrm{I}$ & $\times \pm \mathrm{S} \times$ & $\times \pm \mathrm{S} \times$ \\
$\times \pm \mathrm{S} \times$ & $2.37 \pm 0.041$ & $3.79 \pm 0.074^{\mathrm{b}}$ \\
$1.35 \pm 0.039$ & $\mathrm{II}$ & $\mathrm{V}$ \\
\hline $10-30$ months $(\mathrm{n}=20)$ & $\times \pm \mathrm{S} \times$ & $\times \pm \mathrm{S} \times$ \\
$\mathrm{I}$ & $2.26 \pm 0.059$ & $3.57 \pm 0.087^{\mathrm{a}}$ \\
$\times \pm \mathrm{S} \times$ & $\mathrm{III}$ & $\mathrm{V}$ \\
$1.30 \pm 0.038$ & $\times \pm \mathrm{S} \times$ & $\times \pm \mathrm{S} \times$ \\
\hline 31 months and older $(\mathrm{n}=51)$ & $2.39 \pm 0.036$ & $3.59 \pm 0.049^{\mathrm{a}}$ \\
\hline $\mathrm{I}$ & & $\mathbf{P}<\mathbf{0 . 0 5}$ \\
\hline$\times \mathrm{S} \times$ & $\mathrm{P}>0.05$ & \\
$1.41 \pm 0.037$ & $\mathrm{P}$ value & \\
$\mathrm{P}>0.05$ & $\mathrm{P}$ &
\end{tabular}

ms: millisecond, $\mathrm{n}$ : sample number, $\times \pm \mathrm{S} \times$ : mean \pm standard error of mean 


\section{Discussion}

There is only one study that examined the state of deafness in Kangal shepherd dogs (Koçkaya et al., 2019). In this study, the latency intervals belonging to the sense of hearing of Kangal shepherd dogs have been identified and presented as normative data for the first time in Table 1. This normative data can be used as reference interval in clinical examinations and future studies on the sense of hearing of Kangal shepherd dogs. Since it has been reported that the interpretation of the clinical ABR devices is mostly based on the latency values (Parlak, 2014), latency values have been used for the clinical ABR device in this study as well. In ABR devices, low frequency the wave latencies I, III and V can be better detected in comparison to other wave latencies (Parlak, 2014). For this reason, the wave latencies I, III and V have been used as parameters in this study as well. In the studies performed, values close to $80 \mathrm{db}$ were used as the upper limit (Shiu et al., 1997; Selvaraj et al., 2018). In addition, it is reported that the highest value should be used for hearing tests in clinical studies (Parlak, 2014). Therefore, $80 \mathrm{db}$ was preferred in this study.

It has been reported that the latency intervals of the sense of hearing are fixed and stable in healthy individuals and that the most commonly used wave latency is the wave latency V (Akyıldız, 2007). The graph of the wave latency V used can be utilized in the detection of conductive hearing losses. It has been stated that the extension of this wave latency may be associated with hearing loss (Muş and Özdamar, 1996). In this study, it is considered that the values obtained other than the wave reference $\mathrm{V}$ latency intervals at $80 \mathrm{db} \mathrm{HL}$ and are given in Table 1, should be evaluated clinically.

It has been reported that sex and age are among the non-pathological factors of individuals affecting the ABR device (Parlak, 2014). In this study, the comparison of normative data as to whether they vary according to these factors was also conducted.

It has been reported that the difference between the wave latencies between two ears of humans should be at most $0.4 \mathrm{~ms}$ (Muş and Özdamar, 1996). In another study conducted on humans, it was found that there was no difference between the two ears at $90 \mathrm{~dB}$ in terms of wave latency V (Parlak, 2014). Similarly, in this study, when the animals were evaluated in general, the difference between the minimum, maximum and average values of the wave latencies I, III and V were found to be 0.15-0.05$0.04, \quad 0.03-0.35-0.02$ and $0.02-0.67-0.09$ respectively (Table 1) and that there is no statistically significant difference between the two ears in terms of wave latency values (Table 2).
It has been reported that in humans, there is no difference between the sexes in the latency duration in neonates and children, but that it is shorter in women than in men among adults (Muş and Özdamar, 1996). In this study, when all animals were evaluated according to sex in general, it was found that latency duration was longer in males (Table 3), but this difference was not statistically significant $(\mathrm{P}>0.05)$.

It has been reported that there is a difference between the wave latencies between neonates and children and adults in humans and that the wave latency $\mathrm{V}$ decreases with aging (Parlak, 2014). In this study, the grouping of Kangal shepherd dogs according to age has been conducted based on the age intervals in which the head diameters rapidly grows according to the statements of the breeders. It was found that the V. wave latency was higher in the dogs belonging to the 20 days-9 months age interval, which represents the puppy category, than those in other categories (Table 4 ) and that this finding is statistically significant $(\mathrm{P}<0.05)$. It has been reported that absolute latencies in humans between the ages of 1824 are quite close to adult values (Akyıldı, 2007). Similarly, in this study, it was found that the wave latency $\mathrm{V}$ was close to each other and statistically insignificant $(\mathrm{P}>0.05)$ in the groups between 10-30 months and 31 months-over (Table 4).

\section{Acknowledgement}

The authors acknowledge the contributions of breeders and Kangal district governorship to sampling efforts.

\section{Funding Information}

This research was supported by the Scientific Research Project Fund of Sivas Cumhuriyet University under the project number $\mathrm{V}-043$.

\section{Author's Contributions}

Mustafa Koçkaya: Carried out field work. $\mathrm{He}$ conceived of the study and participated in its design and coordination and helped to draft the manuscript

Yusuf Özşensoy: Carried out field work. He participated in the design of the study and performed the statistical analysis and helped to draft the manuscript

Hakan Murat: Carried out field work. He helped to draft the manuscript

\section{Competing Interests}

The authors declare that there is no conflict of interests regarding the publication of this article. All authors read and approved the final manuscript. 


\section{References}

Akyıldız, N., 2007. Kulak Hastalıkları ve Mikrocerrahisi. 2: 177-187. Bilimsel Tıp Yayınevi, Ankara.

Akyıldız, N., 1998. Kulak Hastalıkları ve Mikrocerrahisi. İşitme Fizyolojisi, 1: 77-128. Bilimsel Tıp Yayınevi, Ankara.

Ballenger, J.J. and J.B. Snow, 2000. Otorinolaringoloji baş ve boyun cerrahisi. İşitme ve Vestibüler Sistemlerin Fizyolojisi, 15: 879-900.

Case, L.P., 2005. The Dog: Its Behavior, Nutrition and Health. 2nd Edn., Blackwell Publishing, UK. ISBN-10: 0813812542.

Comito, B., K.E. Knowles and G.M. Strain, 2012. Congenital deafness in Jack Russell terriers: prevalence and association with phenotype. Vet. J., 193: 404-407. DOI: 10.1016/j.tvj1.2012.02.018.

Cummings, C.W., J.M. Fredrickson, L.A. Harker, C.J. Krause and D.E. Schüller, 1998. Anatomy of the skull base, temporal bone, external ear and middle ear. Mosby Year Book St. Louise, 4: 2533-2546.

Dalziel, D.J., B.M. Uthman, S.P. McGorray and R.L. Reep, 2003. Seizure-alert dogs: A review and preliminary study. Seizure, 12: 115-120. DOI: $10.1016 / \mathrm{S} 105913110200225 \mathrm{X}$

Hayes, G.M., E.J. Friend and N.D. Jeffery, 2010. Relationship between pharyngeal conformation and otitis media with effusion in Cavalier King Charles spaniels. Vet. Record, 167: 55-58.

DOI: $10.1136 /$ vr.b4886

Kartay, D., 2003. Türk Çoban Köpeği Kangal, Altındağ Grafik Matbaacılık, İzmir.

Keele, C.A., E. Neil and N. Joels, 1985. Samson Wright's applied physiology. Proceedings of the 13th (Edn), Oxford Univ Press, London, New York, Toronto, USA. ISBN10: 0192632108

Koçkaya, M. and M. Şireli, 2015. Comparison of behavioural and physiological responses of Kangal dogs in different livestock flocks. Ankara Üniversitesi Vet. Fakültesi Dergisi, 62: 261-267. DOI: $10.1501 /$ Vetfak 0000002690

Koçkaya, M., Y. Özşensoy and H. Murat. 2019. Deafness risk estimation analysis of native genetic resource Kangal shepherd dog breed: Sivas province example. Am. J. Animal Vet. Sci., 14: 115-121. DOI: 10.3844/ajavsp.2019.115.121

Lv, P., D. Wei and E.N. Yamoah, 2010. K $\mathrm{K}_{\mathrm{v}}$ 7-type channel currents in spiral ganglion neurons: Involvement in sensorineural hearing loss. J. Biol. Chem., 285: 34699-34707.

DOI: $10.1074 /$ jbc.M110.136192
Muş, N. and Ö. Özdamar, 1996. İşitsel Beyin Sap1 Cevaplarının Normal Değişimleri. In: İşitsel beyin sapı cevapları, Muş, N. and Özdamar, Ö. (Eds), Gülhanae Askeri Tıp Akademisi, Ankara.

Paparella, M.M., D.A. Shumrick, J.L. Gluckman and W.L. Meyerhoffet, 1991. Electrophysiology of the Peripheral Auditory System. Otolaryngology 3th edition W.B. Saunders Company, Philadelphia, 1: 219-253.

Parlak, A.F., 2014. Normal işitmeye sahip yetişkinlerde chirp uyaranı normatif değerleri. Unpublished dissertation in partial fulfillment of the requirements for the degree of Master, Başkent Üniversitesi, Sağllk Bilimleri Enstitüsü, Ankara, Turkey.

Sanders, C.R., 2000. The impact of guide dogs on the identity of people with visual impairments. Anthrozoös, 13: 131-139. DOI: $10.2752 / 089279300786999815$

Selvaraj, P., M. Sivakumari, S. Yogeshpriya, M. Venkatesan and M. Veeras et al., 2018. Deafness evaluation and brainstem auditory evoked response (BAER) testing in dogs. J. Entomol. Zool. Studies, 6: 1473-1475.

Shiu, J.N., K.J. Munro and C.L. Cox, 1997. Normative auditory brainstem response data for hearing threshold and neuro-otological diagnosis in the dog. J. Small Animal Practice, 38: 103-107. DOI: $10.1111 /$ j.1748-5827.1997.tb03328.x

SPSS Inc., 2013. SPSS 22.0 for Windows Evalution Version.

Stepien, I., L. Stepien and E. Lubinska, 1990. Function of dog's auditory cortex in tests involving auditory location cues and directional instrumental response. Acta Neurobiol. Exp., 50: 1-12.

Strain, G.M., 2011. Physiology of the Auditory System. In: Deafness in Dogs and Cats, Strain, G.M. (Ed.), CABI, Wallingford, UK, pp: 23-39. ISBN-10: 9781 845939373.

Strain, G.M., 2012. Canine deafness. Veterinary Clinics North America-Small Animal Practice, 42: 12091224. DOI: $10.1016 /$ j.cvsm.2012.08.010

Yaman, S.G., 2004. Kobaylarda dehidrasyonun iç kulak üzerine etkisinin distorsiyon ürünü otoakustik emisyon ölçüm yöntemiyle fonksiyonel olarak araştırılması. Unpublished dissertation in partial fulfillment of the requirements for the degree of Doctor of Philosophy, T.C. Sağlık Bakanlığı Şişli Eftal Eğitim ve Araştırma Hastanesi, İstanbul, Turkey. 